\title{
PHYSIOLOGICAL PARAMETERS, HAIR COAT MORPHOLOGICAL CHARACTERISTICS AND TEMPERATURE GRADIENTS IN HOLSTEIN- GYR CROSSBRED COWS
}

\author{
PARÂMETROS FISIOLÓGICOS, CARACTERÍSTICAS MORFOLÓGICAS DO \\ PELAME E GRADIENTES TÉRMICOS DE VACAS CRUZADAS HOLANDÊS-GIR
}
Patrícia Ferreira Fernandes da CRUZ ${ }^{1}$; Camylla Pedrosa MONTEIRO²; Ednaldo Carvalho GUIMARÃES ${ }^{3}$; Robson Carlos ANTUNES ${ }^{4}$; Mara Regina Bueno de Mattos NASCIMENTO ${ }^{4}$

1. MS in Veterinary Sciences, Federal University of Uberlândia - UFU, Uberlândia, MG, Brazil. patricia0p@ hotmail.com; 2. BS in Veterinary Sciences - UFU, Uberlândia, MG, Brazil; 3. PhD Faculty member, School of Mathematics - UFU, Uberlândia, MG, Brazil; 4. PhD, Faculty member, School of Veterinary Medicine, UFU, Uberlândia, MG, Brazil.

\begin{abstract}
The aim of this study was to assess physiological parameters, hair coat morphological characteristics and temperature gradients in crossbred Holstein-Gyr cows in the municipality of Tapira, Minas Gerais (MG), Brazil. Forty-nine lactating cows from six Holstein $(\mathrm{H})$ and $\mathrm{Gyr}(\mathrm{G})$ genetic groups $(1 / 4 \mathrm{H} 3 / 4 \mathrm{G}, 3 / 8 \mathrm{H} 5 / 8 \mathrm{G}, 1 / 2 \mathrm{H}$ $1 / 2 \mathrm{G}, 5 / 8 \mathrm{H} 3 / 8 \mathrm{G}, 3 / 4 \mathrm{H} 1 / 4 \mathrm{G}$ and $7 / 8 \mathrm{H} 1 / 8 \mathrm{G}$ ) were distributed in a completely randomized design. The dry-bulb temperature and relative humidity were recorded, and the temperature and humidity index (THI) was calculated. The rectal temperature, respiratory rate and body surface temperature were measured, as were hair thickness, numbers, length and

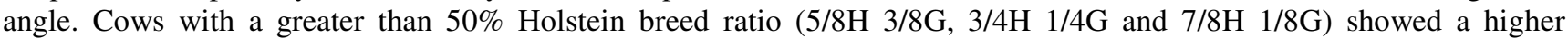
respiratory rate and greater hair length than animals with genetic composition equal to or greater than $50 \%$ Zebu $(1 / 2 \mathrm{H}$ $1 / 2 \mathrm{G}, 3 / 8 \mathrm{H} 5 / 8 \mathrm{G}$ and $1 / 4 \mathrm{H} 3 / 4 \mathrm{G}$ ). Animals from the $1 / 2$ and $1 / 4 \mathrm{HG}$ genetic groups showed the greatest hair angle $(\mathrm{P}<0.05)$. With respect to climatic characteristics, the examined locality was within the thermoneutral zone and therefore did not impose conditions of thermal stress. The animals exhibited thermoregulation and hair coat characteristics that were within physiological parameters.
\end{abstract}

KEYWORDS: Dairy Cattle. Thermal Environment. Physiological Responses.

\section{INTRODUCTION}

The selection of animals showing higher survivability, production and reproduction and knowledge related to the adaptability of breeds exploited under tropical environments is crucial to increase milk productivity in Brazil (FAÇANHA et al., 2013). Animals exhibit a maximum production capacity within their thermoneutral zone, which is characterized by a temperature range that allows their thermal comfort (AZEVEDO et al., 2005). However, cattle may exhibit difficulties in increasing heat loss to the environment under heat stress conditions, resulting in increased body temperature, which may compromise their production and reproductive performance (SILVA et al., 2012).

Changes in the respiratory rate and rectal temperature are related to the physiological response to stress (COSTA; SILVA et al., 2009). These parameters may be used to assess thermal comfort and other characteristics of an animal's outer shell, specifically its thickness, structure and thermal insulation properties, in addition to other environmental factors, including solar radiation, atmospheric pressure, temperature and relative humidity (SILVA, 2000). The effects of heat stress are more pronounced in animals with high metabolic rates, including lactating dairy cows (MARTELLO et al., 2004), whose genetics mostly derive from temperate regions. These animals are sensitive to temperature variations, leading to behavioral and physiological changes that cause reduced milk production (TOSETTO et al., 2014). Therefore, it is important to provide thermal comfort to dairy cows to ensure their welfare and optimal production performance (PEREIRA, 2005).

Crossbreeding of zebu cattle with European dairy breeds has been widely performed to increase the potential of animals for milk production in the tropics (SYRSTAD, 1996). The Gyrolando breed, resulting from crossbreeding of the Holstein and Gyr breeds, is one such example. European-origin breeds are specialized for milk production (FACÓ et al., 2002), while Zebu cattle show increased heat resistance due to differences in metabolic rate, sweating rate, food and water consumption and coat characteristics and color (BLACKSHAW; BLACKSHAW, 1994). However, animals resulting from crossbreeding of the Holstein and Gyr breeds may also be sensitive to heat stress effects, 
especially those whose genetic composition is closer to the Holstein breed (BORGES et al., 2012).

The effects of heat stress on the productive efficiency (FACÓ et al., 2002; ALMEIDA et al., 2010), the expression of behaviors indicative of thermal discomfort (BORGES et al., 2012) and thermoregulatory characteristics in summer (LIMA et al., 2013) have been reported for Gyrolando cows. However, research studies on the different genetic groups that make up the Gyrolando breed are scarce. This experiment aimed to assess physiological parameters, hair coat morphological characteristics and temperature gradients in lactating cows with different Holstein and Gyr genetic compositions.

\section{MATERIAL AND METHODS}

This study was performed in October 2013, in the municipality of Tapira $\left(46^{\circ} 49^{\prime} 12^{\prime \prime} \mathrm{W}\right.$, $19^{\circ} 54^{\prime} 55^{\prime \prime S}$ ), at an altitude of $1,091 \mathrm{~m}$, in the state of Minas Gerais (MG), Brazil. The regional climate is Cwa and is semi-wet with a dry winter and hot and rainy summer (SÁ JÚNIOR, 2009). This study was approved by the Animal Ethics Committee of the Federal University of Uberlândia, under registration number 127/13.

October was chosen because, according to NOVAIS (2011), it is the hottest month in the Alto Paranaíba and Triângulo Mineiro regions due to more sunlight and less cloud cover relative to the rest of the year.

The location for the study was chosen because of the artisanal Minas cheese. According to Brasil (2006), the best Minas cheese is produced in Minas Gerais state because this state has different geographical regions with specific characteristics conditioned by physical and natural factors that result in characteristic natural pastures and lead to the development of specific bacteria that multiply in each of these microclimates and give each cheese a specific appearance and taste.

Forty-nine multiparous lactating cows with a mean body mass of $470.71 \pm 5.00 \mathrm{~kg}$, from six Holstein $(\mathrm{H})$ and Gyr $(\mathrm{G})$ genetic groups $(1 / 4 \mathrm{H}$ $3 / 4 \mathrm{G} \quad(\mathrm{n}=9), 3 / 8 \mathrm{H} 5 / 8 \mathrm{G} \quad(\mathrm{n}=8), 1 / 2 \mathrm{H} 1 / 2 \mathrm{G} \quad(\mathrm{n}=8)$, $5 / 8 \mathrm{H} 3 / 8 \mathrm{G}(\mathrm{n}=8), 3 / 4 \mathrm{H} 1 / 4 \mathrm{G}(\mathrm{n}=9)$ and $7 / 8 \mathrm{H} 1 / 8 \mathrm{G}$ $(n=7))$ were distributed in a completely randomized design, and each animal comprised one replicate. These animals were kept on pasture with a shaded area and were provided with water, salt and feed $a d$ libitum. The animals were kept in an outdoor pen with a chute. In the morning (9 to $11 \mathrm{am}$ ), the respiratory rate, rectal temperature and body surface temperature of each animal were measured. Hair coat thickness measurements and hair samples were collected from each animal between 2 and $4 \mathrm{pm}$. Measurements were performed from October 8-10, 2013.

The respiratory rate ( $\mathrm{RR}$, mov. $\mathrm{min}^{-1}$ ) was evaluated by visually counting the oscillations of the left flank. Rectal temperature (RT, $\left.{ }^{\circ} \mathrm{C}\right)$ was measured in the animal's rectum for one minute using a digital veterinary thermometer $(\mathrm{G}-\mathrm{Tech} \AA, \pm$ $0.2^{\circ} \mathrm{C}$ accuracy), ranging up to $44^{\circ} \mathrm{C}$. Body surface temperature $\left(\mathrm{ST},{ }^{\circ} \mathrm{C}\right)$ was measured on the forehead, withers, groin and hock using a digital infrared thermometer (Instrutemp® model DT 8530 and 0.95 emissivity, $\pm 0.2^{\circ} \mathrm{C} / \pm 2 \%$ accuracy), and the mean was calculated. Hair coat thickness (HCT, mm) was measured $20 \mathrm{~cm}$ below the vertebral column in the middle thoracic region using an analog caliper (Mitutoyo $®, \pm 0.05 \mathrm{~mm}$ accuracy), according to Silva (2000). A hair sample was then collected from the same region where coat thickness was measured using electrician's pliers adapted to quantify number of hairs $\left(\mathrm{NH}\right.$, hairs. $\left.\mathrm{cm}^{-2}\right)$; the length of the ten longest hairs ( $\mathrm{LH}, \mathrm{mm})$ was measured using a digital caliper (Western $® P R O, \pm 0.3 \mathrm{~mm} / \pm 0.01$ accuracy), and the hair angle (HA, degrees) was measured according to Silva (2000).

A sensor/recorder (404A HOMIS $®, \pm 1.0$ (2.0) dry-bulb temperature accuracy, \pm 3.0 relative humidity accuracy and $\pm 2.0( \pm 4.0)$ dew point accuracy) installed near the collection site was used to measure the air dry-bulb temperature (Tdb), relative humidity $(\mathrm{RH})$ and dew point temperature (Tdp) at 5-minute intervals. Subsequently, the temperature and humidity index (THI) was calculated using the equation proposed by THOM (1958). Temperature gradients were calculated based on the differences between the rectal temperature and body surface temperature (RT-ST), between the body surface temperature and air drybulb temperature (ST-Tdb) and between the rectal temperature and air dry-bulb temperature (RT-Tdb).

The data were subjected to analysis of variance in a completely randomized design, followed by the Scott-Knott test for comparison of means according to procedures reported in Banzatto and Kronka (2013). For the analysis of variance, the assumptions of normality of error and homoscedasticity of variance were assessed using the Anderson-Darling and Levene tests, respectively, and the assumptions of model additivity and error independence were assessed through the graphical analysis of residuals. Statistical analyses were performed using ACTION (2013) and Sisvar (FERREIRA, 2011) software, adopting a 5\% significance level. 


\section{RESULTS AND DISCUSSION}

The climate data, including $\mathrm{Tdb}, \mathrm{RH}$, and the THI, indicated maintenance within the thermal comfort zone of crossbred Holstein-Gyr cows. The mean, minimum and maximum values of the drybulb temperature were $21^{\circ}, 18^{\circ}$ and $26^{\circ} \mathrm{C}$, respectively. $\mathrm{Tdb}$ remained within the thermoneutral range, which can vary from 5 to $31^{\circ} \mathrm{C}$ and is suitable for the thermal comfort of crossbred lactating cows according to PEREIRA (2005). The mean, minimum and maximum values of $\mathrm{RH}$ were $69 \%$, $49 \%$ and $95 \%$, respectively. The mean $\mathrm{RH}$ was close to $70 \%$, and the maximum value exceeded that rate, which is considered the thermal comfort threshold for warm-climate lactating cows (NÄÄS; ARCARO JÚNIOR, 2001). High air temperature and humidity may adversely affect thermal comfort, thereby reducing milk production (PEREIRA, 2005); however, these climatic conditions were not observed in this study. The mean, minimum and maximum values of the THI were 67,65 and 72 , respectively. These values are all lower than 75 , which is considered the thermal comfort threshold for Holstein-Zebu crossbred cows (AZEVEDO et al., 2005).
Rectal temperature is one of the most sensitive indicators of the physiological response to heat stress in cattle because it remains almost constant under normal conditions (SILANIKOVE, 2000). The RT values of the Holstein-Gyr crossbred cows were not different from each other (Table 1) and remained within the physiological range. Rectal temperatures ranging from 37.5 to $39.3^{\circ} \mathrm{C}$ represent normal physiological values for cattle according to Silva (2000). Almeida et al. (2010) recorded values ranging from 38.0 to $38.2^{\circ} \mathrm{C}$ in multiparous lactating Gyrolando cows under a climate control system in the summer. Azevedo et al. (2005) recorded increased rectal temperatures in $1 / 2,3 / 4$ and $7 / 8$ Holstein-Zebu (HZ) animals as THI values increased; these observations indicated higher sensitivity of $7 / 8 \mathrm{HZ}$ animals compared with the other genetic groups, although similar results were not obtained in the present study because the examined animals were not challenged by heat stress. There is a difference between cattle breeds regarding the capacity to regulate rectal temperature, for which the average is higher in Bos taurus taurus than in Bos taurus indicus (FINCH, 1986), and Zebu animals are more tolerant of heat stress (SILANIKOVE, 2000).

Table 1. Mean and standard deviation of physiological parameters: rectal temperature $\left(\mathrm{RT},{ }^{\circ} \mathrm{C}\right)$, respiratory rate $\left(\mathrm{RR}\right.$, mov. $\left.\mathrm{min}^{-1}\right)$, body surface temperature $\left(\mathrm{ST},{ }^{\circ} \mathrm{C}\right)$; hair coat morphological characteristics: hair coat thickness (HCT, mm), number of hairs $\left(\mathrm{NH}\right.$, hairs. $\left.\mathrm{cm}^{2}\right)$, hair length $(\mathrm{LH}, \mathrm{mm})$ and hair angle (HA, degrees); and temperature gradients: difference between rectal temperature and body surface temperature (RT-ST), between body surface temperature and dry-bulb temperature (ST $-\mathrm{Tdb})$ and between rectal temperature and dry-bulb temperature $(\mathrm{RT}-\mathrm{Tdb})$ in Holstein-Gyr crossbred cows in Tapira, MG, Brazil.

\begin{tabular}{|c|c|c|c|c|c|c|}
\hline \multicolumn{7}{|c|}{ Genetic group } \\
\hline & 1/4H 3/4G & 3/8H 5/8G & $1 / 2 \mathrm{H} \mathrm{1/2G}$ & $5 / 8 H$ 3/8G & 3/4H 1/4G & 7/8H 1/8G \\
\hline \multicolumn{7}{|c|}{ Physiological parameters } \\
\hline RT & $38.5 \pm 0.36$ & $38.6 \pm 0.35$ & $38.5 \pm 0.36$ & $38.6 \pm 0.42$ & .53 & 0.46 \\
\hline $\mathbf{R R}$ & $33.6 \pm 3.6^{\mathrm{b}}$ & $35.6 \pm 2.3^{\mathrm{b}}$ & 33. & $37.0 \pm 4.00^{\mathrm{a}}$ & $01^{\mathrm{a}}$ & $70^{\mathrm{a}}$ \\
\hline ST & 3 & $29.9 \pm 1.04$ & 30.1 & $30.3 \pm 2.02$ & & \\
\hline \multicolumn{7}{|c|}{ Hair coat morphological characteristics } \\
\hline HCT & .18 & $2.2 \pm 0.58$ & & $2.8 \pm 0.68$ & 2.5 & .15 \\
\hline NH & $1071 \pm 237.7$ & $1276 \pm 550.9$ & 127 & $1299 \pm 223.7$ & $1435 \pm 325.4$ & $1589 \pm 544.9$ \\
\hline LH & $9 \pm 1.38^{b}$ & $6.5 \pm 1.27^{\mathrm{b}}$ & $6.2 \pm$ & $8.3 \pm 2.49^{\mathrm{a}}$ & $10.1 \pm 4.6^{\mathrm{a}}$ & $8.5 \pm 4.38^{\mathrm{a}}$ \\
\hline HA & $25.5 \pm 6.21^{\mathrm{a}}$ & $21.5 \pm 7.45^{\mathrm{b}}$ & $25.8 \pm 10.98^{\mathrm{a}}$ & $21.3 \pm 8.06^{\mathrm{b}}$ & $16.9 \pm 5.92^{\mathrm{b}}$ & $23.2 \pm 7.24^{\mathrm{b}}$ \\
\hline \multicolumn{7}{|c|}{ Temperature gradients } \\
\hline RT-ST & $6 \pm 1.27$ & $8.6 \pm 1.03$ & $8.4 \pm 1.97$ & $8.3 \pm 1.81$ & $8.1 \pm 1.12$ & $8.1 \pm 1.63$ \\
\hline ST-Tdb & $10.0 \pm 1.79$ & $9.6 \pm 1.59$ & $10.1 \pm 0.99$ & $10.1 \pm 1.43$ & $9.9 \pm 13.12$ & $9.1 \pm 1.53$ \\
\hline RT-Tdb & $18.2 \pm 0.36$ & $18.3 \pm 0.57$ & $18.3 \pm 0.53$ & $18.4 \pm 0.35$ & $18.5 \pm 0.42$ & $18.7 \pm 0.20$ \\
\hline
\end{tabular}

Means followed by different letters in the same row are significantly different according to the Scott-Knott test (5\%).

Respiratory rate measurements are a key means of characterizing thermal discomfort in cattle (FERREIRA et al., 2006) because an increase in this rate is the first visible sign that the animal is under heat stress (VILELA et al., 2013). Furthermore, cows exhibiting an increased respiratory rate for an extended period show decreased feed intake and rumination, and thus, milk production decreases 
(KADZERE et al., 2002). The $1 / 4 \mathrm{H} 3 / 4 \mathrm{G}, 3 / 8 \mathrm{H}$ $5 / 8 \mathrm{G}$ and $1 / 2 \mathrm{H} 1 / 2 \mathrm{G}$ cows presented lower respiratory rates $(\mathrm{P}<0.05)$ than the other genetic groups (Table 1). However, this parameter was within normal physiological values for all animals, which may range between 18 and 60 mov. $\mathrm{min}^{-1}$ for lactating cows (HAHN et al., 1997). This result was expected because these animals show the closest genetic composition to Indian cattle, which are typically more resistant to heat and other environmental stressors (BÓ et al., 2003). Lima et al. (2013) recorded lower respiratory rates in $1 / 2 \mathrm{H}$ $1 / 2 \mathrm{G}$ animals $\left(42\right.$ mov.min $\left.{ }^{1}\right)$ than in $5 / 8 \mathrm{H} 3 / 8 \mathrm{G}$ (49.5 mov. $\mathrm{min}^{-1}$ ) and $3 / 4 \mathrm{H} 1 / 4 \mathrm{G}$ (58 mov. $\left.\mathrm{min}^{-1}\right)$ animals, indicating that the $1 / 2 \mathrm{H} 1 / 2 \mathrm{G}$ animals exhibit a greater capacity to lose heat through their skin. In a region characterized by a Cwa climate and environmental conditions with increasing THI values, Azevedo et al. (2005) recorded higher respiratory rates in $3 / 4$ and $7 / 8 \mathrm{HZ}$ animals than in $1 / 2 \mathrm{HZ}$ animals, as observed in the present study, thus indicating a higher sensitivity to heat stress in animals harboring a higher proportion of Holstein genes within their genetic composition.

The body surface temperature was not significantly different $(\mathrm{P}>0.05)$ between the different genetic groups, with the average remaining below $35^{\circ} \mathrm{C}$ (Table 1). The results of this study corroborate the findings of Azevedo et al. (2005), who observed that different genetic groups showed minimal differences in ST values, though these values were slightly higher in $1 / 2 \mathrm{HZ}$ animals than in $3 / 4$ and $7 / 8 \mathrm{HZ}$ animals, possibly because of the darker coat color of the $1 / 2 \mathrm{HZ}$ animals. A temperature of $35^{\circ} \mathrm{C}$ is sufficient for heat exchange to occur via conduction according to Collier et al. (2006). Lima et al. (2013) noted higher average ST values in $3 / 4$ cows than in $1 / 2$ and $5 / 8$ HG cattle.

The mean values of hair coat thickness were not significantly different $(\mathrm{P}>0.05)$ between the different genetic groups (Table 1). The recorded values were similar to those reported in Holstein cows in winter $(2.88 \mathrm{~mm}$; Mata and Silva et al., 2013) and higher than those recorded in crossbred dairy cows in a semiarid region $(1.93 \mathrm{~mm}$; Façanha et al., 2010). These authors reported higher hair coat thickness values in animals harboring high proportions of Holstein genes than in animals derived from crossbreeding with Guzera cows, which are more adapted to tropical environments and, thus, exhibit a thinner coat with short, wellsettled hairs, which contributes to a greater loss of heat energy.

The number of hairs was not significantly different $(\mathrm{P}>0.05)$ between genetic groups (Table 1).
Although hairs protect the epidermis against the deleterious effects of solar radiation, it is most advantageous for cattle to exhibit the lowest possible thermal insulation in warm environments, provided their epidermis is pigmented, even though it absorbs more radiation and is heated to a greater extent (SILVA et al., 2009). Maia et al. (2003) found that the hair coat of Holstein cows in tropical environments exhibits shorter, thicker and less numerous hairs in dark patches, facilitating thermolysis and evaporative processes.

The 5/8, 3/4 and 7/8 HG cows showed greater mean hair lengths $(\mathrm{P}<0.05)$ than the other genetic groups (Table 1). A likely explanation for this result is their genetic composition, which includes a high percentage of Holstein genes. Maia et al. (2003) recorded mean hair lengths of $12.05 \pm$ 0.100 and $14.26 \pm 0.110 \mathrm{~mm}$ in the black and white hair coats of Holstein cows, respectively, between autumn and spring in tropical environments, and these values were greater than those found in the present study. Azevedo et al. (2005) recorded a longer hair length in crossbred cows with a genetic composition closer to the Holstein breed, while the opposite was true in animals with high Zebu ratios, as observed in the present study. The presence of shorter hairs is an adaptive characteristic of Zebu animals to tropical regions, dominated by high temperatures, thereby favoring heat dissipation to the environment (SILVA, 2000).

The mean hair angles recorded in the $3 / 8 \mathrm{H}$ 5/8G, 5/8H 3/8G, 3/4 $1 / 4 \mathrm{G}$ and $7 / 8 \mathrm{H} 1 / 8 \mathrm{G}$ cows were smaller $(\mathrm{P}<0.05)$ compared with the $1 / 2 \mathrm{H} 1 / 2 \mathrm{G}$ and $1 / 4 \mathrm{H} 3 / 4 \mathrm{G}$ genetic groups (Table 1). Maia et al. (2003) recorded HA values of 11.83 and 11.64 degrees, respectively, for black and white patches in Holstein cows. In the Holstein breed, shorter and thinner hairs, fewer hairs per unit area and a greater hair angle are desirable traits for animals in tropical environments with predominantly black coats, while the opposite traits are desirable for those with predominantly white hairs because their epidermis is less protected against solar radiation according to these authors (MAIA et al., 2003).

The mean values for the temperature gradients were not significantly different $(\mathrm{P}>0.05)$ between genetic groups (Table 1). Reduced RT-ST and ST-Tdb temperature gradients indicate that animals exhibit a reduced ability to lose heat via conduction and convection (SOUZA JUNIOR et al., 2008). Higher RT-Tdb gradients are related to increased resistance to heat stress, and the values obtained in the present study are consistent with the mild conditions of the regional climate. 


\section{CONCLUSION}

With respect to climatic characteristics, Tapira, MG, in the spring was within the thermoneutral zone and therefore did not impose thermal stress on the various examined genetic groups of crossbred Holstein-Gyr cows. Thus, no large variations in thermoregulatory responses were observed. These findings suffice to demonstrate the greater adaptability to hot climates of cattle with higher proportions of Zebu genes.

RESUMO: Objetivou-se avaliar parâmetros fisiológicos, características morfológicas de pelame e gradientes térmicos de vacas cruzadas Holandês-Gir no município de Tapira, MG. Foram utilizadas 49 vacas em lactação de seis grupos genéticos Holandês $(\mathrm{H})$ e Gir $(\mathrm{G})$ : 1/4H 3/4G, 3/8H 5/8G, 1/2H 1/2G, 5/8H 3/8G, 3/4H 1/4G e 7/8H 1/8G distribuídas em delineamento inteiramente ao acaso. A temperatura de bulbo seco e umidade relativa foram registradas e calculou-se o índice de temperatura e umidade (ITU). A temperatura retal, frequência respiratória, temperatura da superfície corporal, espessura, número, comprimento e inclinação dos pelos foram mensurados. Vacas com proporção maior que $50 \%$ da raça Holandesa $(5 / 8 \mathrm{H} 3 / 8 \mathrm{G}, 3 / 4 \mathrm{H} 1 / 4 \mathrm{G}$ e $7 / 8 \mathrm{H} 1 / 8 \mathrm{G})$ apresentaram frequência respiratória e comprimento dos pelos maiores em comparação aos animais com composição genética igual ou superior a 50\% do Zebu (1/2H 1/2G, 3/8H 5/8G e 1/4H 3/4G). Os animais do grupo genético 1/2 e 1/4 HG apresentaram a maior inclinação de pelo $(\mathrm{P}<0,05)$. As características climáticas da localidade estiveram dentro da zona de termoneutralidade, não impondo desta forma condições de estresse térmico e os animais apresentaram características de termorregulação e de pelame dentro dos parâmetros fisiológicos.

PALAVRAS-CHAVE: Bovino Leiteiro. Ambiente Térmico. Respostas Fisiológicas.

\section{REFERENCES}

ACTION. Portal Action. Available from: <www.portalaction.com.br.> Accessed: September 04. 2013.

ALMEIDA, G. L. P. et al. Investimento em climatização na pré-ordenha de vacas Girolando e seus efeitos na produção de leite. Revista Brasileira de Engenharia Agrícola e Ambiental, Campina Grande, v. 14, n. 12, p. 1337-1344, 2010. http://dx.doi.org/10.1590/S141543662010001200013.

AZEVEDO, M. et al. Estimativas de níveis críticos superiores do índice de temperatura e umidade para vacas leiteiras 1/2, 3/4 e 7/8 Holandês-Zebú, em lactação. Revista Brasileira de Zootecnia, Viçosa, v. 34, n. 6, p. 2000-2008, 2005. http://dx.doi.org/10.1590/S1516-35982005000600025.

BANZATTO, D. A.; KRONKA, S. N. Experimentação agrícola. Jaboticabal: FUNEP, 2013, 237p.

BLACKSHAW, J. K.; BLACKSHAW, A. W. Heat stress in cattle and the effect of shade on production and behavior: a review. Australian Journal of Experimental Agriculture, Melbourne, v. 34, p. 285-295, 1994. http://dx.doi.org/10.1071/EA9940285

BÓ, G. A. et al. Pattern and manipulation of follicular development in Bos indicus cattle. Animal

Reproduction Science, Amsterdam, v. 78, p. 307-326, 2003. http://dx.doi.org/10.1016/S0378-4320(03)000976

BORGES, C. R. A. et al. Heterogeneous genetic cows of three genetic groups in feedlot system in the state of Pernambuco, Brazil. Acta Scientiarum. Animal Sciences, Maringá, v. 34, p. 91-96, 2012. http://dx.doi.org/10.4025/actascianimsci.v34i1.11306. http://dx.doi.org/10.4025/actascianimsci.v34i1.11306

BRASIL. Ministério da Cultura. Instituto do Patrimônio Histórico e Artístico Nacional (IPHAN). Inventário Nacional de Referências Culturais (INRC). Queijo artesanal de Minas: patrimônio cultural do Brasil. Belo Horizonte, 2006. 137 p. Available from: <http://portal.iphan.gov.br/portal/baixaFcdAnexo.do?id=3223>. Accessed: September 04. 2014. 
COLLIER, R. J. et al. Major advances associated with environmental effects on dairy cattle. Journal of Dairy Science, Champaign, v. 89, p. 1244-1253, 2006. http://dx.doi.org/10.3168/jds.S0022-0302(06)72193-2

COSTA e SILVA, E. V. et al. Bem-estar, ambiência e saúde animal. In: Congresso Brasileiro de Buiatria, 8, 2009, Belo Horizonte. Anais... MG Belo Horizonte: Associação Brasileira de Buiatria, 2009.

FAÇANHA, D. A. E. et al. Variação anual de características morfológicas e da temperatura de superfície do pelame de vacas da raça Holandesa em ambiente semiárido. Revista Brasileira de Zootecnia, Viçosa, v. 39, n. 4, p. 837-844, 2010. http://dx.doi.org/10.1590/S1516-35982010000400020.

FAÇANHA, D. A. E. et al. Tendências metodológicas para avaliação da adaptabilidade ao ambiente tropical. Revista Brasileira de Saúde e Produção Animal, Salvador, v. 14, n. 1, p. 91-103, 2013.

FACÓ, O. et al. Análise do desempenho produtivo de diversos grupos genéticos Holandês x Gir no Brasil. Revista Brasileira de Zootecnia, Viçosa, v. 31, n. 5, p. 1944-1952, 2002. http://dx.doi.org/10.1590/S151635982002000800010.

FERREIRA, F. et al. Parâmetros fisiológicos de bovinos cruzados submetidos ao estresse calórico. Arquivo Brasileiro de Medicina Veterinária e Zootecnia, Belo Horizonte, v. 58, n. 5, p. 732-738, 2006. http://dx.doi.org/10.1590/S0102-09352006000500005.

FERREIRA, D. F. Sisvar: a computer system for statistical analysis. Ciência e Agrotecnologia, Lavras, v. 35, n.6, p. 1039-1042, 2011. http://dx.doi.org/10.1590/S1413-70542011000600001.

FINCH, V. A. Body temperature in beef cattle: Its control and relevance to production in the tropics. Journal of Animal Science, Champaign, v. 62, p. 531-542, 1986.

HAHN, G. L. et al. Cattle respiration rate as a function of ambient temperature. Transactions of American Society of Agricultural Engineering, St. Joseph, v. 40, p. 97-121, 1997.

KADZERE, C. T. et al. Heat stress in lactating dairy cows: a review. Livestock Production Science, Amsterdam, v. 77, p. 59-91, 2002. http://dx.doi.org/10.1016/S0301-6226(01)00330-X

LIMA, I. A. et al. Thermoregulation of Gyrolando cows during summertime, in Pernambuco, State, Brasil. Acta Scientiarum. Animal Sciences, Maringá, v. 35, n. 2, p. 193-199, 2013. http://dx.doi.org/10.4025/actascianimsci.v35i2.16591.

MAIA, A. S. C. et al. Características do pelame de vacas holandesas em ambiente tropical: um estudo genético e adaptativo. Revista Brasileira de Zootecnia, Viçosa, v. 32, n. 4, p. 843-853, 2003. http://dx.doi.org/10.1590/S1516-35982003000400009.

MARTELLO, L. S. et al. Respostas fisiológicas e produtivas de vacas holandesas em lactação submetidas a diferentes ambientes. Revista Brasileira de Zootecnia, Viçosa, v. 33, n. 1, p. 3-11, 2004. http://dx.doi.org/10.1590/S1516-35982004000100022.

MATA e SILVA, B. C. et al. Características morfológicas do pelame de vacas holandesas puras por cruza na região semiárida de Minas Gerais. Arquivo Brasileiro de Medicina Veterinária e Zootecnia, Belo Horizonte, v. 65, n. 6, p. 1767-1772, 2013. http://dx.doi.org/10.1590/S0102-09352013000600026.

NÄÄS, I. A.; ARCARO JÚNIOR, I. Influência de ventilação e aspersão em sistemas de sombreamento artificial para vacas em lactação em condições de calor. Revista Brasileira de Engenharia Agrícola e Ambiental, Campina Grande, v. 5, n. 1, p. 139-142, 2001. http://dx.doi.org/10.1590/S141543662001000100026. 
NOVAIS, G. T. Caracterização climática da mesorregião do Triângulo Mineiro/Alto Paranaíba e entorno da Serra da Canastra (MG). 2011. 175 f. Dissertação (Mestrado em Geografia) - Curso de Pós-graduação em Geografia, Universidade Federal de Uberlândia, Uberlândia, 2011.

PEREIRA, C. C. J. Fundamentos de bioclimatologia aplicados à produção animal. Belo Horizonte: FEPMVZ, 2005, 195p.

SÁ JÚNIOR, A. de. Aplicação da classificação de Köppen para o zoneamento climático do Estado de Minas Gerais. 2009. 101f. Dissertação (Mestrado em Engenharia Agrícola) - Curso de Pós-graduação em Engenharia Agrícola, Universidade Federal de Lavras, Lavras, 2009.

SILANIKOVE, N. Effects of heat stress on the welfare of extensively managed domestic ruminants. Livestock Production Science, Amsterdam, v. 67, p. 1-18, 2000. http://dx.doi.org/10.1016/S03016226(00)00162-7

SILVA, I. M. et al: Análise espacial das condições térmicas do ambiente pré-ordenha de bovinos leiteiros sob regimes de climatização. Revista Brasileira de Engenharia Agrícola e ambiental, Campina Grande, v. 16, n. 8, p. 903-909, 2012. http://dx.doi.org/10.1590/S1415-43662012000800013.

SILVA, R. G. Introdução à bioclimatologia animal. São Paulo: Nobel, 2000. 286p.

SILVA, R. G. et al. Thermal radiation absorbed by dairy cows in the pasture. International Journal of Biometeorology, Lisse, v. 47, p. 23, 2009.

SOUZA JUNIOR, J. B. F. et al. Temperatura da superfície corporal e fluxo de calor convectivo em vacas holandesas expostas à radiação solar direta no Semi-árido. In: Congresso Nordestino de produção animal, 5 ., 2008, Aracaju. Anais... Aracaju: SNPA, 2008, p. 1-3.

SYRSTAD, O. Dairy cattle crossbreeding in the tropics: choice of crossbreeding strategy. Tropical Animal Health and Production, Edinburgh, v. 28, p. 223-229, 1996. http://dx.doi.org/10.1007/BF02240940

THOM, E. C. Cooling degree: day air conditioning, heating and ventilating. Transactions of the American Society of Heat Refrigeration and Air Condition Engeneering, New York, v. 55, p. 65-72, 1958.

TOSETTO, M. R. et al. Influência do macroclima e do microclima sobre conforto térmico de vacas leiteiras. Journal of Animal Behaviour and Biometeorology, Mossoró, v. 2, n. 1, p. 6-10, 2014. http://dx.doi.org/10.14269/2318-1265.v02n01a02.

VILELA, R. A. et al. Respostas fisiológicas e comportamentais de vacas Holandesas mantidas em sistema adiabático evaporativo. Pesquisa Veterinária Brasileira, Rio de Janeiro, v. 33, p. 1379-1384, 2013. 